\title{
Pengolahan Data Satelit Sentinel-1 dan Pasut untuk Mengkaji Area Genangan Akibat Banjir Pasang di Kecamatan Sayung, Kabupaten Demak
}

\author{
Tri Abdul Hidayat ${ }^{{ }^{*}}$, Muhammad Helmi ${ }^{1}$, Sugeng Widada $^{1}$, Alfi Satriadi $^{1}$, Heryoso Setiyono $^{1}$, \\ Aris Ismanto ${ }^{1}$, Muh Yusuf ${ }^{1}$ \\ ${ }^{I}$ Departemen Oseanografi, Fakultas Perikanan dan Ilmu Kelautan, Universitas Diponegoro \\ Jl. Prof. Sudarto, SH., Tembalang, Semarang, Central Java (50275) Indonesia \\ Email:*triabdulha@gmail.com
}

\begin{abstract}
Abstrak
Perubahan iklim dapat menyebabkan terjadinya peningkatan temperatur laut yang berakibat pencairan es di kutub, sehingga berdampak pada kenaikan permukaan air laut. Naiknya muka air laut menimbulkan ancaman bagi wilayah yang berada di pinggir pantai, salah satunya adalah Kecamatan Sayung. Salah satu dampak yang ditimbulkan adalah penggenangan daratan oleh banjir pasang. Kondisi genangan rob di Sayung diperparah dengan terjadinya penurunan muka tanah yang mempunyai andil dalam perluasan genangan banjir pasang. Tujuan dari penelitian ini adalah untuk menganalisa secara spasial daerah yang tergenang akibat naiknya air pasang pada tahun 2018 dan menganalisa laju penurunan muka tanah pada tahun 2017 - 2019 di Kecamatan Sayung. Ketinggian muka pasang tinggi tertinggi di Kecamatan Sayung pada tahun 2018 dihitung dengan menggunakan metode admiralty adalah 238,27 cm dan MSL pada tahun yang sama adalah 176,93 cm. Besarnya penurunan muka tanah yang terjadi di Kecamatan Sayung didapatkan dengan mengolah data Sentinel-1 menggunakan metode DInSAR. Desa dengan tingkat penurunan muka tanah tertinggi adalah Tugu, Timbulsloko, dan Sayung dengan rata-rata penurunan sebesar $10,68 \pm 1,63 \mathrm{~cm} /$ tahun, $8,71 \pm 1,78 \mathrm{~cm} /$ tahun dan $8,35 \pm 1,39 \mathrm{~cm} /$ tahun. Luas daerah yang tergenang banjir pasang pada tahun 2018 adalah 3350,29 hektar. Desa yang tergenang total pada saat banjir pasang Bedono, Gemulak, Sidogemah, Surodadi, Timbulsloko, dan Tugu.
\end{abstract}

Kata kunci : Banjir pasang, Penurunan muka tanah, Kecamatan Sayung

\begin{abstract}
Climate change cause an increase in sea temperatures which results in melting of polar ice caps, thus affecting sea level rise. Sea level rise pose a threat to areas on the coast, Sayung District is one of it. One of the impacts is inundation area by tidal floods. The condition of tidal inundation was exacerbated by land subsidence which contributed to the expansion of tidal floods area. The purpose of this study is to spatially analyze areas were flooded due to highest high water level in 2018 and analyze the rate of land subsidence in 2017 - 2019 in Sayung District. The highest high water level in Sayung Subdistrict in 2018 calculated using the admiralty method was $238,27 \mathrm{~cm}$ and the mean sea level in the same year is $176,93 \mathrm{~cm}$. The amount of land subsidence that occurred in Sayung District was obtained by processing Sentinel-1 data using the DInSAR method. The villages with the highest level of land subsidence Tugu, Timbulsloko, and Surodadi with an average decline of 10,68 $\pm 1,63 \mathrm{~cm} /$ year, $8,71+1,78 \mathrm{~cm} /$ year, and 8,35 $\pm 1,39 \mathrm{~cm} /$ year. The total area that was flooded by tidal floods was 3350,29 hectares. The villages that were totally inundated during the tidal flood were Bedono, Gemulak, Sidogemah, Surodadi, Timbulsloko, and Tugu.
\end{abstract}

Keywords: Tidal floods, Land subsidence, Sayung District

\section{PENDAHULUAN}

Fenomena banjir pasang yang terjadi di pesisir utara Pulau Jawa merupakan akibat dari perubahan muka air laut karena pemanasan global (Surya et al., 2019). Berdasarkan riset yang telah dilakukan oleh Febrianto (2017), data kenaikan permukaan air laut Indonesia mengalami tren positif dengan kenaikan muka air laut tertinggi sebesar $23,5 \mathrm{~mm} /$ tahun. Kondisi kenaikan permukaan air laut di pantai utara Jawa memiliki variasi yang lebih besar. Selain itu, banjir pasang terjadi akibat penurunan muka tanah (Marfai \& King, 2007). Menurut (Kusuma et al., 2013), daerah pesisir Demak mengalami banjir pasang ketika pasang tertinggi dan kembali surut pada saat pasang terendah. Banjir pasang menggenangi kawasan pemukiman di beberapa desa pesisir Kabupaten Demak, termasuk desa yang terdapat di 
Kecamatan Sayung (Muryani et al., 2016). Permasalahan banjir pasang terus berlanjut sampai saat ini. Kecamatan Sayung merupakan salah satu kecamatan di Kabupaten Demak dan berbatasan langsung dengan pantai utara Jawa. Karakteristik tanah di daerah pantai utara Jawa ini sebagian besar terbentuk dari endapan alluvial yang masih berumur muda dan belum terlitifikasi, sehingga masih dalam proses konsolidasi dan kompaksi. Tanah yang masih dalam proses konsolidasi dan kompaksi dapat mengakibatkan terjadinya penurunan muka tanah (Al Akbar et al., 2015). Muka air laut semakin meningkat dan permukaan tanah semakin turun mengakibatkan luasan area genangan di Kecamatan Sayung semakin meluas. Adanya genangan akibat banjir pasang pada Kecamatan Sayung menuntut adanya tindakan pengelolaan bencana. Salah satu langkah awal pengelolaan yang dapat dilakukan adalah memetakan area genangan banjir pasang. Data muka air laut, tingkat penurunan muka tanah, dan elevasi muka tanah dikumpulkan dan diolah untuk mengamati luasan genangan yang terjadi. Penelitian ini dilakukan sebagai langkah memberikan informasi dalam melakukan mitigasi bencana agar dampak dari banjir pasang dapat diminimalkan.

\section{MATERI DAN METODE}

Riset ini dilakukan di Kecamatan Sayung yang ditunjukkan pada Gambar 1. Kecamatan Sayung adalah bagian dari Kabupten Demak, Provinsi Jawa Tengah. Dari Bappeda Kabupaten Demak (2019), diketahui wilayah Kecamatan Sayung memiliki jarak terjauh dari barat ke timur sepanjang $8 \mathrm{~km}$ dan dari utara ke selatan sepanjang $16 \mathrm{~km}$ dengan total luas wilayah secara administratif adalah $78,80 \mathrm{~km}^{2}$.

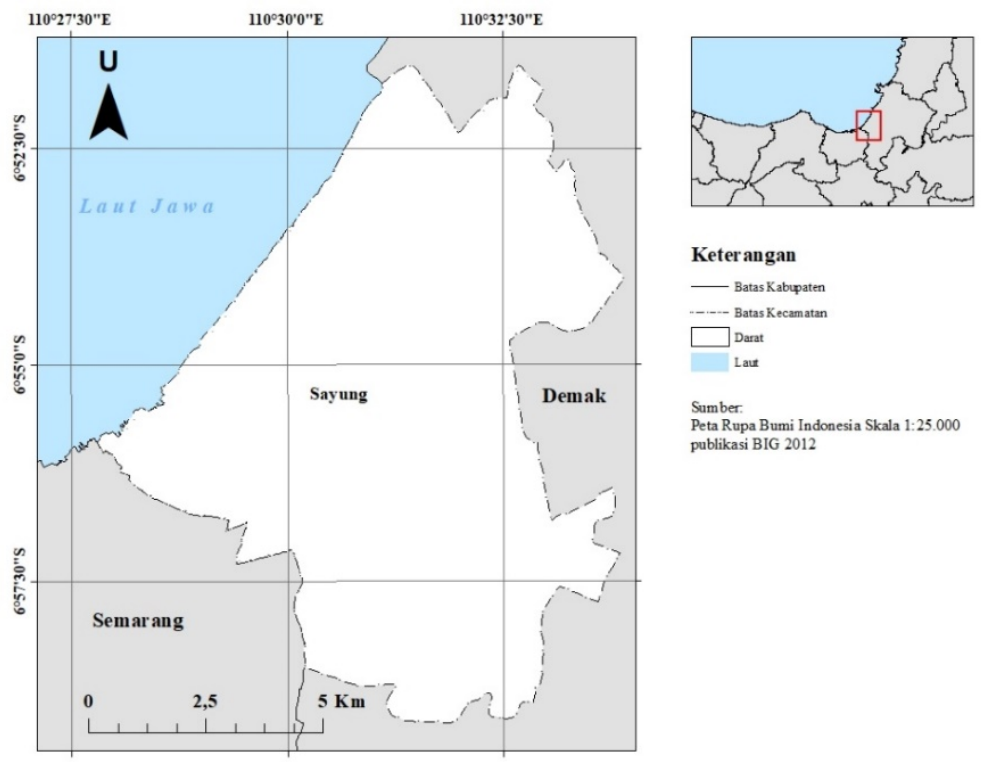

Gambar 1. Area Studi

Penelitian ini menggunakan data utama data hasil wawancara dengan penduduk Desa di Kecamatan Sayung sebagai narasumbernya. Data penunjang berupa data pasang surut, data DEMNAS, data DEM SRTM $1 \mathrm{sec}$ HGT, citra resolusi tinggi, dan data Sentinel-1. Data pasang surut selama tahun 2018 yang digunakan diperoleh dari BIG. Data DEMNAS yang digunakan diperoleh dari situs BIG. Data DEM SRTM 1 sec HGT merupakan hasil unduhan dari software SNAP. Citra yang digunakan antara lain Sentinel 2A rekaman Oktober 2018, Sentinel 1A rekaman Maret 2017 dan Juli 2019. Metode pengolahan data dilakukan dengan beberapa tahapan yaitu pengolahan data pasang surut menggunakan metode Admiralty, pengolahan data DEM untuk peta topografi menggunakan metode topo to raster, pengolahan penurunan muka tanah menggunakan metode DInSAR, dan pengolahan area genangan banjir menggunakan raster calculator tool pada ArcGIS. Laju penurunan muka tanah dihitung dengan rumus:

$$
\text { Velocity } P M T=\frac{\text { Nilai } P M T * 365}{\text { Selang waktu akuisisi pasangan citra (dalam hari })}
$$




\section{HASIL DAN PEMBAHASAN}

Berdasarkan hasil perhitungan dengan metode admiralty rata-rata nilai MSL rata-rata tahun 2018 di perairan Kecamatan Sayung adalah 176,93 cm dan nilai HHWL adalah 238,27 cm, sehingga tunggang pasut rata-rata tahun 2018 adalah $61,34 \mathrm{~cm}$. Grafik HHWL per bulan dan HHWL rerata ditunjukkan dalam Gambar 2. Hasil perhitungan nilai Formzahl perairan Kecamatan Sayung adalah 1,18 hingga 1,85, sehingga tipe pasutnya adalah campuran condong harian tunggal atau campuran condong harian ganda. Hasil penelitian ini sama dengan penelitian sebelumnya yang dilakukan oleh (Widada et al., 2012) dan (Subardjo dan Ario, 2015) yang juga memperoleh tipe pasang surut campuran condong ke harian tunggal. Hal ini berarti satu hari terjadi satu kali air pasang dan satu kali air surut, tetapi kadang-kadang untuk sementara waktu terjadi dua kali pasang dan dua kali surut dengan tinggi dan periode yang sangat berbeda.

Tabel 1. Komponen Harmonik Pasang Surut di Perairan Demak

\begin{tabular}{ccccccccccc}
\hline Bulan & S0 & M2 & S2 & N2 & K1 & O1 & M4 & MS4 & K2 & P1 \\
\hline Jan-18 & 176,84 & 9,74 & 4,59 & 3,67 & 19,71 & 6,45 & 0,60 & 0,36 & 1,24 & 6,50 \\
\hline Feb-18 & 184,42 & 9,33 & 5,66 & 3,74 & 16,48 & 4,54 & 0,58 & 0,74 & 1,53 & 5,44 \\
\hline Mar-18 & 168,83 & 11,55 & 7,97 & 5,26 & 19,31 & 8,70 & 0,77 & 0,13 & 2,15 & 6,37 \\
\hline Apr-18 & 174,87 & 12,99 & 9,06 & 5,05 & 23,10 & 10,45 & 0,14 & 0,72 & 2,45 & 7,62 \\
\hline Mei-18 & 183,31 & 10,88 & 9,17 & 3,18 & 23,40 & 10,81 & 0,51 & 0,68 & 2,48 & 7,72 \\
\hline Jun-18 & 178,88 & 8,97 & 10,46 & 3,13 & 23,17 & 6,21 & 0,43 & 0,63 & 2,83 & 7,64 \\
\hline Jul-18 & 176,44 & 9,38 & 8,50 & 3,52 & 25,30 & 7,76 & 0,32 & 0,56 & 2,29 & 8,35 \\
\hline Agu-18 & 177,06 & 9,02 & 6,96 & 2,03 & 19,44 & 9,37 & 0,49 & 0,78 & 1,77 & 6,41 \\
\hline Sep-18 & 174,45 & 9,64 & 8,32 & 2,42 & 21,96 & 7,73 & 0,48 & 0,43 & 2,05 & 7,25 \\
\hline Okt-18 & 174,21 & 10,72 & 8,09 & 3,95 & 21,36 & 9,20 & 0,22 & 0,34 & 2,18 & 7,05 \\
\hline Nov-18 & 176,72 & 10,81 & 10,75 & 5,58 & 21,89 & 3,54 & 0,43 & 0,54 & 2,90 & 7,22 \\
\hline Des-18 & 177,15 & 11,03 & 9,36 & 3,73 & 20,75 & 4,57 & 0,54 & 0,47 & 2,53 & 6,85 \\
\hline
\end{tabular}

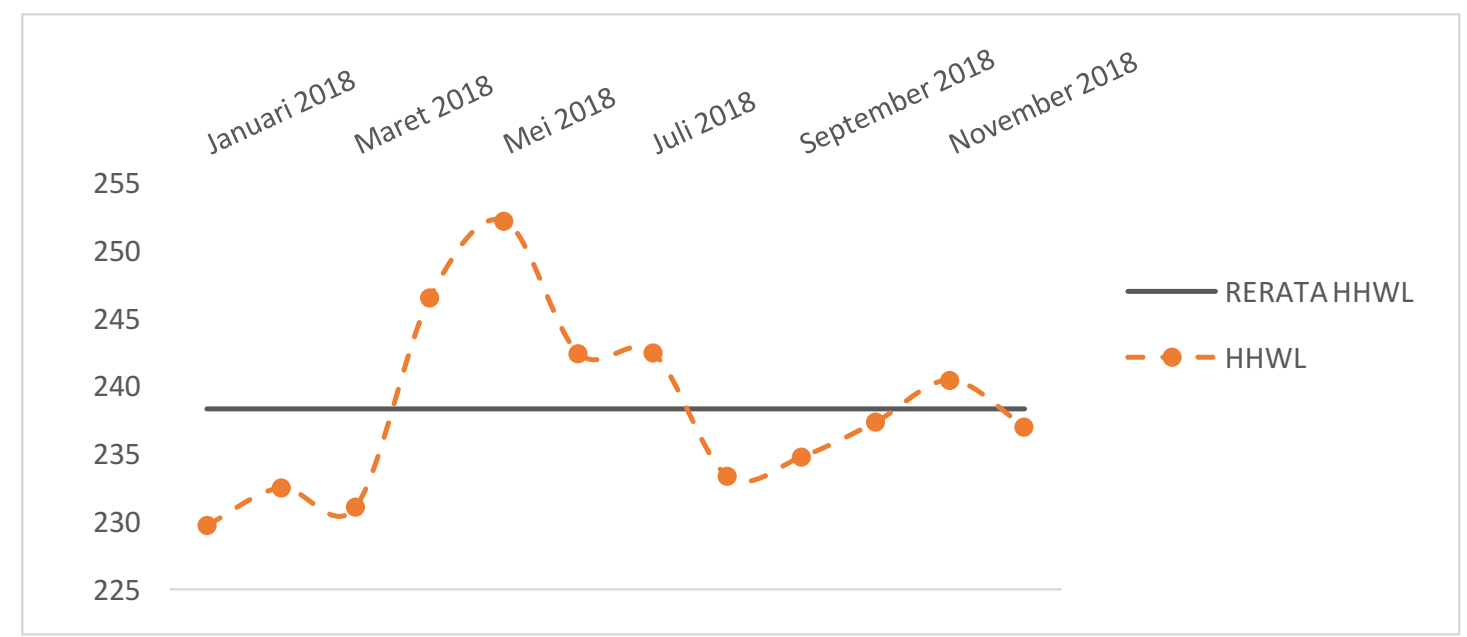

Gambar 2. Grafik Pasang Surut Perairan Semarang 2018

Penurunan muka tanah terjadi di seluruh bagian Kecamatan Sayung dan besarnya penurunan muka tanah bervariasi di setiap desa. Bagian utara Kecamatan Sayung cenderung memiliki nilai penurunan muka tanah lebih besar dibandingkan dengan bagian selatan. Desa dengan tingkat penurunan muka tanah paling tinggi adalah Tugu dan Timbulsloko. Penurunan muka tanah rata-rata tertinggi berada di Desa Tugu, Timbulsloko, dan Sayung dengan nilai penurunan muka tanah sebesar 10,68 \pm $1,63 \mathrm{~cm} /$ tahun, $8,71 \pm 1,78 \mathrm{~cm} / \mathrm{tahun}$, dan $8,35 \pm 1,39 \mathrm{~cm} /$ tahun. Daerah dengan titik penurunan muka 
tanah paling tinggi adalah Desa Tugu dengan nilai penurunan muka tanah sebesar 15,47 $\pm 1,63$ $\mathrm{cm} /$ tahun. Pada desa Tugu terdapat titik dengan penurunan muka tanah sebesar 15,47 $\pm 1,63 \mathrm{~cm} /$ tahun. Hal ini senada dengan penelitian yang telah dilakukan oleh Rahmawan (2016) yang melakukan pengukuran deformasi penurunan muka tanah dengan metode pengukuran GPS. Metode CSEM yang digunakan dalam penelitian tersebut menunjukkan terjadi penurunan muka tanah sebesar $-5,82 \mathrm{~cm} /$ tahun yang terjadi pada desa Tugu yang merupakan desa dengan penurunan muka tanah paling besar pada penelitian tersebut. Pada bagian selatan pantura Semarang - Demak, desa yang mengalami penurunan muka tanah terbesar terdapat pada desa Sayung. Pada desa Sayung terdapat titik dengan penurunan muka tanah sebesar 12,88 $\pm 1,39 \mathrm{~cm} /$ tahun. Rerata penurunan muka tanah yang terjadi pada desa Sayung adalah $8,35 \pm 1,39 \mathrm{~cm} /$ tahun.

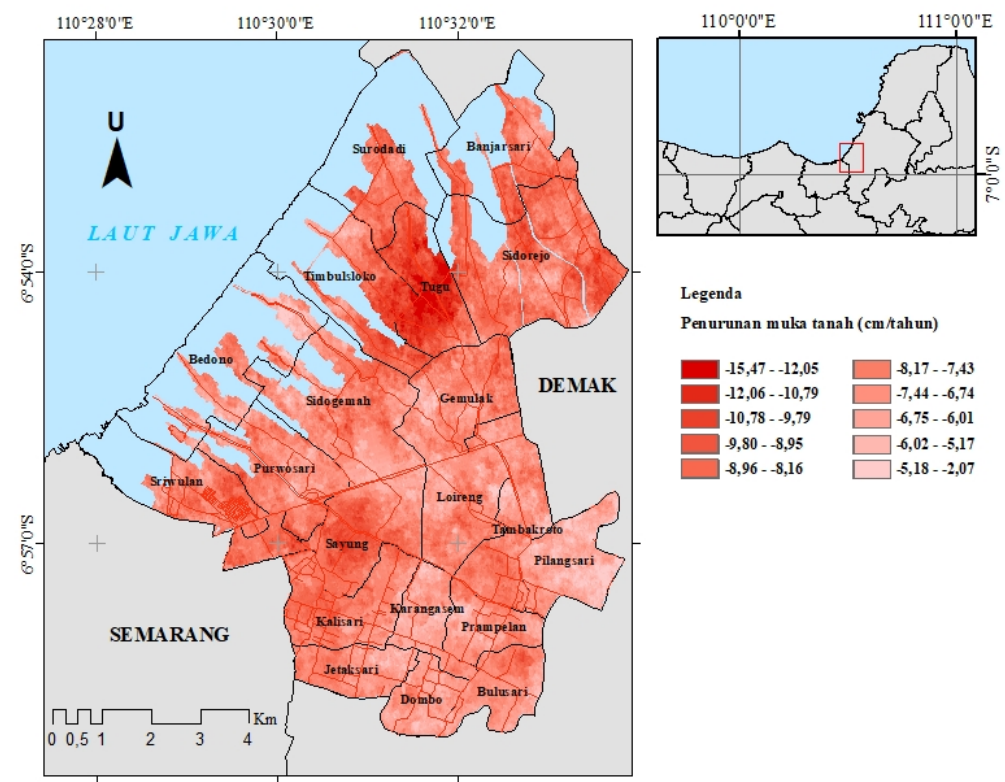

Gambar 3. Penurunan Muka Tanah (cm/tahun)

Validasi dilakukan untuk mengetahui hasil yang diperoleh dari metode DInSAR jika dibandingkan dengan hasil penelitian mengenai penurunan muka tanah yang dilakukan di Kecamatan Sayung. Perbandingan antara hasil yang diperoleh dengan metode DInSAR pada penelitian ini dengan hasil pengukuran lapangan tersaji dalam tabel 2 .

Tabel 2. Perbandingan Hasil Pengukuran Lapangan dan DInSAR dalam satuan $\mathrm{cm} / \mathrm{tahun}$

\begin{tabular}{llcccc}
\hline No & \multicolumn{1}{c}{ Lokasi } & $\begin{array}{c}\text { Koordinat } \\
\text { X }\end{array}$ & $\begin{array}{c}\text { Koordinat } \\
\text { Y }\end{array}$ & $\begin{array}{c}\text { Pengukuran } \\
\text { Lapangan } \\
\text { (cm/tahun) }\end{array}$ & $\begin{array}{c}\text { DInSAR } \\
\text { (cm/tahun) }\end{array}$ \\
\hline 1 & Dinas Kebersihan & 110,4487 & $-6,9600$ & 8,9 & $-9,33284$ \\
2 & Gebangsari, Genuksari & 110,4695 & $-6,9636$ & 7,9 & $-6,7564$ \\
3 & Pospol Kartini Cipta & 110,4345 & $-6,9570$ & 2,7 & $-2,5378$ \\
4 & Barito. Muktiharjo & 110,4421 & $-6,9719$ & 2,6 & $-3,7276$ \\
5 & Jln. Soekarno Hatta No. 10 & 110,4475 & $-6,9767$ & 8,7 & $-9,87258$ \\
\hline
\end{tabular}

Data koordinat yang digunakan untuk validasi berlokasi di sekitaran Kecamatan Genuk, Semarang yang mana merupakan berbatasan langsung di sebelah barat dari lokasi penelitian. Hasil regresi liniernya adalah 0,9131 . 


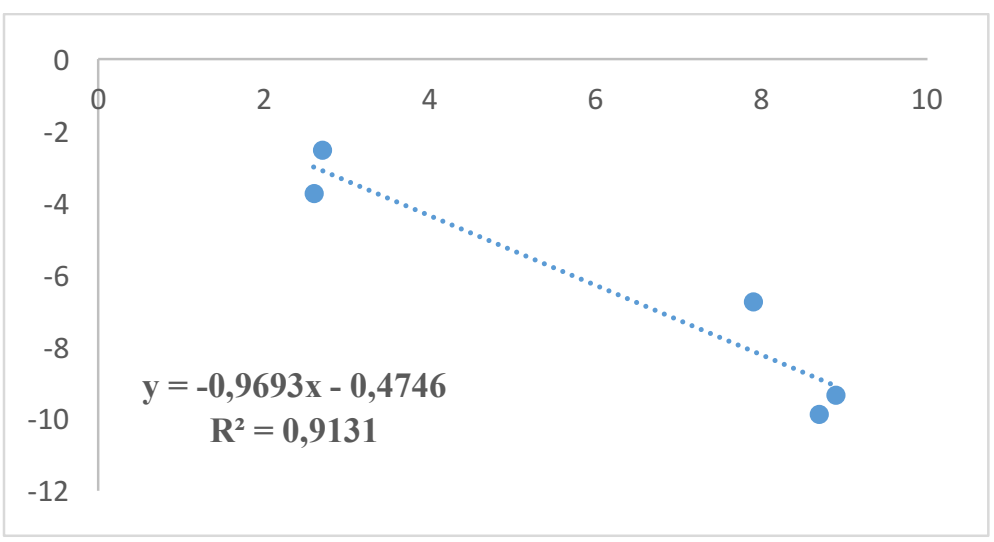

Gambar 4. Grafik Regresi Linier

Kecamatan Sayung merupakan salah satu kecamatan di Kabupaten Demak yang berada di pinggiran Kota Semarang, sehingga perkembangan kawasan industri di wilayah ini juga mulai meningkat. Keberadaan kawasan industri ini dapat menyebabkan penambahan beban di permukaan tanah dikarenakan oleh bangunan industri tersebut. Keberadaan kawasan industri ini juga mempengaruhi aktivitas pemompaan air tanah. Kebutuhan air untuk industri lebih besar jika dibandingkan dengan kebutuhan air untuk rumah tangga. Hal ini menyebabkan terjadinya pemompaan air secara besar-besaran atau overpumping. Kondisi ini menyebabkan adanya rongga di dalam tanah dikarenakan hilangnya air dari pori-pori tanah. Keberadaan rongga ini dan adanya beban di permukaan tanah dapat menyebabkan terjadinya penurunan tanah yang cukup tinggi.

Wilayah kecamatan Sayung memiliki topografi yang bervariasi dengan ketinggian 0 meter - 6,55 meter. Terdapat 20 desa yang ada di Kecamatan Sayung. Daerah sebelah utara jalan pantura cenderung memiliki ketinggian yang lebih rendah dibandingkan daerah sebelah selatan jalan pantura. Ketinggian cenderung bertambah semakin ke selatan. Daerah dengan warna lebih gelap menggambarkan daerah yang memiliki ketinggian yang lebih tinggi. Semakin menjauhi pantai, ketinggian semakin tinggi.

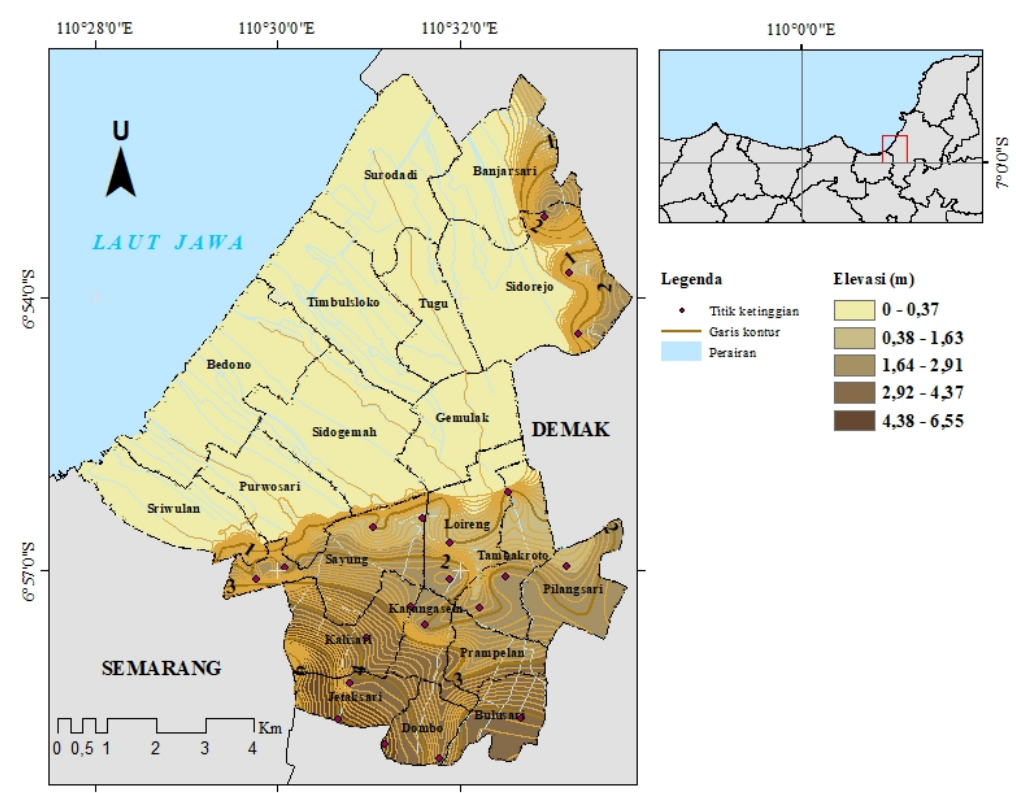

Gambar 5. Peta Ketinggian Tanah Kecamatan Sayung

Wilayah pesisir Sayung merupakan dataran rendah dengan topografi relatif datar, kurang dari $2 \%$, elevasi $0-6,55$ meter di atas permukaan air laut. Topografi yang rendah dan posisi yang dekat dengan garis pantai menyebabkan wilayah tersebut rentan terhadap genangan banjir pasang. Hal ini diperkuat 
oleh pendapat Asrofi (2017) yang menyatakan bahwa parameter yang mempengaruhi daerah genangan pasang selain Highest High Water Level adalah ketinggian tanah, penurunan muka tanah, jarak dari sungai dan jarak dari garis pantai. Hal tersebutlah yang menyebabkan air laut lebih mudah masuk ke daratan.

Kecamatan sayung sering terkena banjir pasang. Luas daerah yang tergenang banjir pasang di Kecamatan Sayung adalah 3350,29 hektar. Desa yang mengalami banjir pasang terluas adalah Desa Sidogemah dengan luas genangan sebesar 545,92 hektar. Desa yang tergenang total saat banjir pasang adalah Bedono, Gemulak, Sidogemah, Surodadi, Timbulsloko, dan Tugu. Hal ini dikarenakan desa tersebut memiliki topografi yang landai dan berada dekat dengan garis pantai. Desa Kalisari merupakan desa yang sangat sedikit terkena dampak genangan banjir pasang, hal tersebut dikarenakan topografi yang relatif lebih tinggi dan jarak desa yang jauh dari garis pantai.

Banjir pasang yang terjadi secara terus menerus mengakibatkan kegiatan warga Kecamatan Sayung menjadi terganggu. Beberapa diantaranya adalah infrasturktur rusak, pemukiman warga terendam, dan beberapa pabrik tutup sementara. Kecenderungan semakin luasnya wilayah genangan banjir pasang setiap tahun dapat menurunkan kualitas lingkungan dan kehidupan masyarakat. Upaya warga yang telah dilakukan dalam pengurangan dampak banjir pasang.

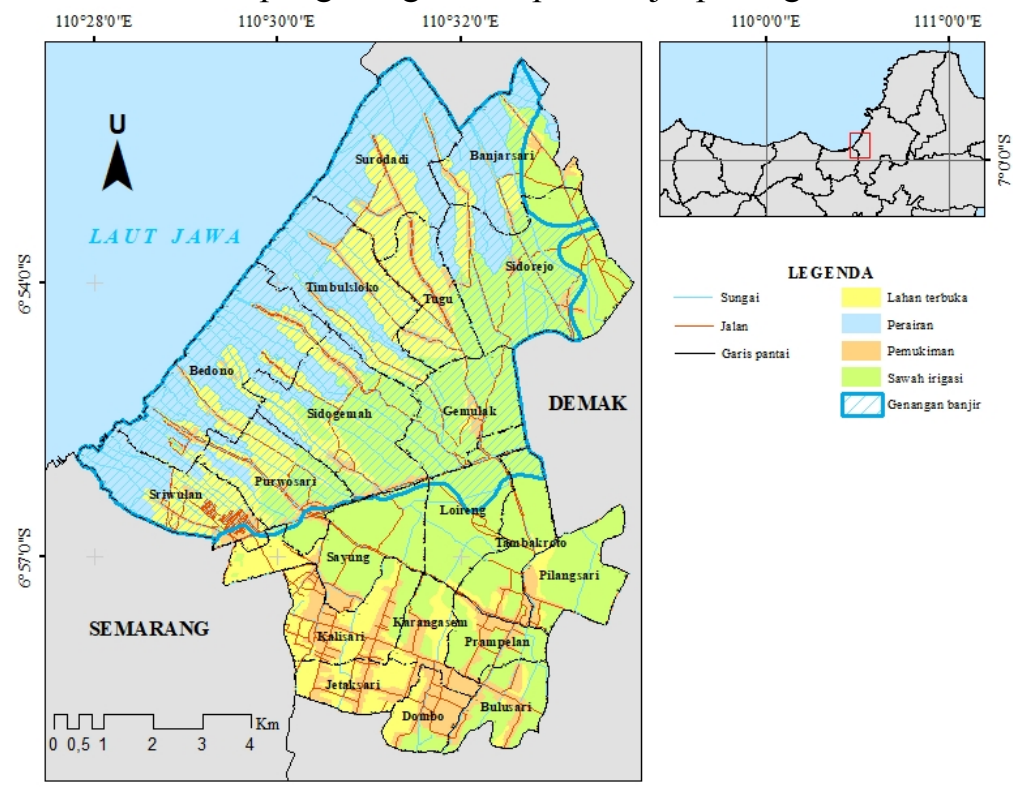

Gambar 6. Peta Genangan Banjir Pasang Kecamatan Sayung

Secara fisik, strategi ini dilakukan untuk mempertahankan fungsi dari bangunan walaupun banjir pasang sedang terjadi. Bentuk yang dilakukan antara lain memodifikasi dan merenovasi rumah, pengaman perabot rumah tangga, perbaikan jalan lingkungan. Perlindungan terhadap aset rumah dilakukan warga Kecamatan Sayung dengan berbagai cara menyesuaikan dengan dana yang dimiliki. Warga yang memiliki dana dapat melakukan peninggian rumah dengan mengurug lantai yang kemudian diikuti peninggian dinding dan rangkai atap. Secara sosial, strategi ini dilakukan untuk mempertahankan kegiatan meski sedang terjadi banjir pasang. Ketika warga melaksanakan hajatan pernikahan atau khitanan, warga membuat beberapa alternatif tempat pelaksanaan. Bila hari pelaksanaan terjadi banjir pasang, maka lokasi dipindahkan atau mempercepat tempo pelaksanaan.

\section{KESIMPULAN}

Berdasakan hasil perhitungan dengan metode admiralty, nilai HHWL dan MSLkecamatan Sayung pada tahun 2018 adalah $238,27 \mathrm{~cm}$ dan $176,93 \mathrm{~cm}$, sehingga tunggang pasutnya adalah 61,34. Berdasarkan hasil pengolahan dengan metode DInSAR, penurunan tanah yang terjadi di Kecamatan 
Sayung berkisar 2,61 + 1,29 sampai 15,47 + 1,63 cm/tahun. Genangan banjir pada tahun 2018 berdasarkan nilai tunggang pasut dan data olahan DEM (Digital Elevation Model) terjadi di sebagian besar di Kecamatan Sayung dan luasnya adalah 3350,29 hektar atau 51,12\%.

\section{DAFTAR PUSTAKA}

Al Akbar, T. O., Prasetyo, Y., dan Wijaya, A. P. 2015. Analisis Dampak Penurunan Muka Tanah Terhadap Tingkat Ekonomi Menggunakan Kombinasi Metode DInSAR Dan SIG (Studi Kasus : Kota Semarang). Jurnal Geodesi Undip, 4(4), 136-143.

Asrofi, A., dan Hadmoko. 2017. Strategi Adaptasi Masyarakat Pesisir Dalam Penanganan Bencana Banjir Rob dan Implikasinya Terhadap Ketahanan Wilayah (Studi Di Desa Bedono Kecamatan Sayung Kabupaten Demak Jawa Tengah). Jurnal Ketahanan Nasional, 23(2), 125-144

Febrianto, C. 2017. Studi Fenomena Perubahan Muka Air Laut Menggunakan Data Satelit Altimetri Jason-2 Periode Tahun 2013-2016 (Studi Kasus: Perairan Indonesia).

Kusuma, A., Irwani, I., \& Widada, S. 2013. Identifikasi Daerah Rawan Rob Untuk Evaluasi Tata Ruang Pemukiman Di Kabupaten Demak. Diponegoro Journal of Marine Research, 2(3), 1-5.

Marfai, M. A., \& King, L. 2007. Monitoring land subsidence in Semarang, Indonesia. Environmental Geology, 53(3), 651-659.

Muryani, C., Nugraha, S., dan Prihadi, S. 2016. Impact of Coastal Erosion and Tidal Flood to Land Loss at Sriwulan Village, Sayung, Demak, Central Java Province. Lst International Cohference on Geography and Education (ICGE 2016). Atlantis Press.

Rahmawan, L. E., Yuwono, B. D., Awaluddin, M. 2016. Survei Pemantauan Deformasi Muka Tanah Kawasan Pesisir Menggunakan Metode Pengukuran GPS Di Kabupaten Demak Tahun 2016 (Studi Kasusu: Pesisir Kecamatan Sayung, Demak). Jurnal Geodesi Undip. Vol 5(4), 44-55

Subardjo, P., dan Ario, R. 2015. Genangan Banjir Pasang Pada Kawasan Pemukiman di Kecamatan Sayung, Kabupaten Demak - Provinsi Jawa Tengah. Jurnal Kelautan Tropis, 18(1), 7-12.

Surya, M. Y., He, Z., Xia, Y., \& Li, L. 2019. Impacts of Sea Level Rise and River Discharge on The Hydrodynamics Characteristics of Jakarta Bay (Indonesia). Water (Switzerland), 11(7).

Widada, S., Rochaddi, B., \& Endrawati, H. 2012. Pengaruh Arus Terhadap Genangan Rob di Kecamatan Sayung Kabupaten Demak. Buletin Oseanografi Marina, 1, 31-39. 